\title{
Absence of blood-pressure lowering effect of captopril in anephric patients
}

Captopril (SQ 14225), an orally active competitive inhibitor of angiotensin-I-converting enzyme, is an effective antihypertensive agent in patients with essential hypertension, renovascular hypertension, and hypertension associated with renal insufficiency. ${ }^{1-6}$ Its antihypertensive action has been attributed to blockade of the formation of the vasoconstrictor octapeptide angiotensin II. ${ }^{3}$ Additional mechanisms such as accumulation of bradykinin may play a part in the hypotensive effect, since the kinin-degrading enzyme kininase II is identical with angiotensinconverting enzyme.?

To test captopril's specificity of action we examined the effect of a single oral dose in five anephric patients in whom plasma renin activities were extremely low.

\section{Patients, methods, and results}

Five patients (three women and two men, aged 29-53) had undergone bilateral nephrectomy from two to 11 years before the study and were undergoing long-term haemodialysis. The reasons for nephrectomy were: uncontrollable severe hypertension in four patients (three with essential hypertension, one with progressive systemic sclerosis) and intractable renal infection in one patient (adult polycystic disease). They were all studied as outpatients while adhering to a diet containing $100 \mathrm{mmol}(\mathrm{mEq})$ sodium and $50 \mathrm{mmol}$ (mEq) potassium daily. They had no oedema and showed no clinical or radiological evidence of congestive heart failure. None were receiving vasoactive drugs. The serum concentrations of sodium, potassium, and calcium were normal in all patients. The studies were performed 24 hours after each patient's regular haemodialysis.

Captopril was administered in a single oral dose of $50 \mathrm{mg}$ after blood pressure had been stable for at least half an hour with the patient in an upright, seated position. Blood pressure was measured automatically every two minutes for 30 minutes before the captopril (Arteriosonde, Roche) was given and for 90 minutes afterwards. Blood was obtained from an indwelling venous cannula immediately before and at three successive 30 -minute intervals after administration

\footnotetext{
Rogosin Kidney Centre, Cardiovascular Hypertension Centre, and Division of Urology, New York Hospital-Cornell Medical Centre, New York, New York 10021, USA

BRUCE R LESLIE, MD, assistant professor of medicine

DAVID B CASE, MD, associate professor of medicine

JOHN F SULLIVAN, MD, associate professor of medicine

E DARRACOTT VAUGHAN, Jr, MD, professor of urology
}

of captopril. Plasma renin activity was determined according to the method of Sealey and Laragh. ${ }^{8}$ Mean arterial pressure was calculated as the diastolic pressure plus one-third of the pulse pressure.

The table shows that captopril did not lower blood pressure in any patient. In three patients (cases 1, 2, and 5) the mean arterial pressure rose slightly. Plasma renin activity was extremely low in all patients and did not change substantially in response to captopril.

Effect of captopril on blood pressure, mean arterial pressure, and plasma renin activity in five anephric patients

\begin{tabular}{|c|c|c|c|c|c|c|c|c|c|c|c|c|}
\hline \multirow{3}{*}{$\begin{array}{l}\text { Case } \\
\text { No }\end{array}$} & \multicolumn{12}{|c|}{ Minutes after captopril } \\
\hline & & ntrol & & & 30 & & & 60 & & & 90 & \\
\hline & BP* MA & $\mathrm{AP}+1$ & PRA $\ddagger$ & BP & MAP & PRA & BP & MAP & PRA & BP & MAP & PRA \\
\hline $\begin{array}{ll}1 & 1 \\
2 & 1 \\
3 & 1 \\
4 & 1 \\
5 & 1\end{array}$ & $\begin{array}{l}106 / 70 \\
100 / 70 \\
135 / 70 \\
160 / 105 \\
115 / 40\end{array}$ & $\begin{array}{r}82 \\
80 \\
92 \\
123 \\
65\end{array}$ & $\begin{array}{ll}0.17 & 1 \\
0.30 & 1 \\
0.24 & 1 \\
0.08 & 1 \\
0.12 & 1\end{array}$ & $\begin{array}{l}120 / 76 \\
105 / 75 \\
140 / 70 \\
100 / 105 \\
105 / 60\end{array}$ & $\begin{array}{r}91 \\
85 \\
93 \\
123 \\
75\end{array}$ & $\begin{array}{ll}0.22 & 1 \\
0.31 & 1 \\
0.28 & 1 \\
0.08 & 1 \\
0.12 & 1\end{array}$ & $\begin{array}{l}120 / 78 \\
110 / 80 \\
135 / 70 \\
160 / 105 \\
10 / 60\end{array}$ & $\begin{array}{r}92 \\
90 \\
92 \\
123 \\
77\end{array}$ & $\begin{array}{ll}0.22 & 1 \\
0.31 & 1 \\
0.27 & 1 \\
0.07 & 1 \\
0.14 & 1\end{array}$ & $\begin{array}{l}118 / 76 \\
115 / 80 \\
135 / 70 \\
106 / 105 \\
108 / 60\end{array}$ & $\begin{array}{r}90 \\
88 \\
92 \\
5123 \\
76\end{array}$ & $\begin{array}{l}0.22 \\
0.29 \\
0.27 \\
0.06 \\
0.13\end{array}$ \\
\hline
\end{tabular}

* $\mathrm{BP}=$ Blood pressure in $\mathrm{mm} \mathrm{Hg}$

$+\mathrm{MAP}=$ Mean arterial pressure, calculated as diastolic pressure plus one-third

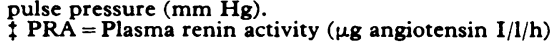

\section{Discussion}

The blood-pressure lowering effect of captopril is associated with a decrease in total peripheral resistance. ${ }^{5}$ Reduction of circulating angiotensin II concentrations by inhibition of converting enzyme has been proposed as a major mechanism for this decrease, since the size of the vasodepressor response to captopril can be predicted by the plasma renin activity before treatment. ${ }^{2} s$

Some investigators, however, have not found a correlation between this activity and the size of blood pressure reduction by captopril, ${ }^{15}$ which suggests that captopril may act by an additional mechanism.

The mechanism most often proposed is one where an accumulation of vasodilator kinins results from inhibition of the kinindegrading enzyme kininase II, which is identical with angiotensin-converting enzyme. Increased concentrations of circulating kinins have been reported after long-term administration of captopril to sodium-depleted $\operatorname{dog} s^{\theta}$ and after intravenous administration of nonapeptide converting-enzyme inhibitor (teprotide, SQ 20881) to patients with essential hypertension. ${ }^{10}$ Despite reductions in blood pressure, however, no increases in plasma bradykinin concentration could be detected during treatment with captopril in patients with essential hypertension or after teprotide infusion in either sodium-depleted normotensive patients ${ }^{10}$ or dogs with one-kidney Goldblatt hypertension. ${ }^{11}$

Our findings support the contention that even though captopril may act by an angiotensin-independent mechanism this action depends on the presence of renal tissue. Although rabbits and sodium-depleted rats have a vasodepressor response to converting-enzyme inhibitor, this effect is absent after bilateral nephrectomy. ${ }^{12-14}$ Moreover, teprotide did not lower blood pressure in anephric patients. ${ }^{15}$ Our findings with captopril in anephric patients agree with these results.

Captopril was recently reported to have lowered blood pressure in an anephric patient, ${ }^{16}$ but to have failed to do so both when the patient was volume loaded and after he had lost $4.3 \mathrm{~kg}$ as a result of ultrafiltration dialysis. Mean arterial pressure rose 
slightly when captopril was given after dialysis (which we also observed in three of our patients). A third captopril test performed after he had lost a further $1.2 \mathrm{~kg}$ led to profound orthostatic hypotension. Although this may have been caused by captopril, nearly two hours elapsed between control pressure measurements and administration of captopril. Failure of physiological buffer mechanisms to maintain blood pressure during this period of intravascular volume depletion, rather than the action of captopril, may have been responsible for the augmented postural decline in blood pressure. In contrast, each patient in our study had a stable blood pressure in an upright, seated position for at least 30 minutes before receiving captopril.

The same authors have recently extended their studies. ${ }^{17}$ They observed reductions in blood pressure in seven anephric patients when captopril was given one hour after haemodialysis. Administering captopril 24 hours after dialysis, however, did not produce a hypotensive effect, which is consistent with our present findings. Thus the fall in blood pressure occurred only when captopril was given soon after dialysis, which suggests a mechanism related to the haemodialysis procedure. Exposure of blood to the haemodialysis membrane may have increased the production of vasodepressor kinins. If the hypotensive response was due to inhibition of kinin degradation by captopril then this response would be expected to be most evident soon after dialysis, as was observed.

Three of our patients showed an increase in mean arterial pressure after captopril. This increase ranged from $12 \%$ to $18 \%$ above the control pressure and reached a maximum 60 minutes after administration. A slight pressor effect after intravenous teprotide in some anephric patients has been observed. ${ }^{15}$ Neither the mechanism of this effect nor its importance in anephric patients or in patients with kidneys receiving captopril is known.

\section{References}

1 Bravo EL, Tarazi RC. Converting enzyme inhibition with an orally active compound in hypertensive man. Hypertension 1979;1:39-46.
2 Brunner HR, Gavras H, Waeber B, et al. Oral angiotensin-converting enzyme inhibitor in long-term treatment of hypertensive patients. Ann Intern Med 1979;90:19-23.

${ }^{3}$ Case DB, Atlas SA, Laragh JH, Sealey JE, Sullivan PA, McKinstry DN. Clinical experience with blockade of the renin-angiotensin-aldosterone system by an oral converting-enzyme inhibitor (SQ 14225, captopril) in hypertensive patients. Progr Cardiovasc Dis 1978;21:195-206.

4 Johnston CI, McGrath BP, Millar JA, Matthews PG. Long-term effects of captopril (SQ 14225) on blood pressure and hormone levels in essential hypertension. Lancet 1979;ii:493-6.

5 Sullivan JM, Ginsburg BA, Ratts TE, et al. Hemodynamic and antihypertensive effects of captopril, an orally active angiotensin converting enzyme inhibitor. Hypertension 1979;1:397-401.

- Vaughan ED Jr, Carey RM, Ayers CR, Peach MJ. Hemodialysis resistant hypertension: control with an orally active inhibitor of angiotensinconverting enzyme. $\mathcal{F}$ Clin Endocrinol Metab 1979;48:869-71.

7 Erdös EG. Conversion of angiotensin I to angiotensin II. Am $\mathcal{f}$ Med 1976;60:749-59.

${ }^{8}$ Sealey JE, Laragh JH. How to do a plasma renin assay. Cardiovasc Med 1977;2:1079-92.

- McCaa RE, Hall JE, McCaa CS. The effects of angiotensin I-converting enzyme inhibitors on arterial blood pressure and urinary sodium excretion. Circ Res 1978;43,suppl I:I-32-I-39.

10 Williams GH, Hollenberg NK. Accentuated vascular and endocrine response to SQ 20881 in hypertension. $N$ Engl f Med 1977;297:184-8.

11 Miller ED Jr, Samuels AI, Haber E, Barger AC. Inhibition of angiotensin conversion and prevention of renal hypertension. Am f Physiol 1975; $228: 448-53$.

12 Jaeger P, Ferguson RK, Brunner HR, Kirchertz EJ, Gavras H. Mechanism of blood pressure reduction by teprotide (SQ 20881) in rats. Kidney Int 1978;13:289-96

13 Murthy VS, Waldron TL, Goldberg ME. The mechanism of bradykinin potentiation after inhibition of angiotensin-converting enzyme by SQ 14225 in conscious rabbits. Circ Res 1978;43,suppl I:I-40-I-45.

14 Thurston H, Swales JD. Converting enzyme inhibitor and saralasin infusion in rats. Circ Res 1978;42:588-92.

15 Case DB, Wallace JM, Keim HJ, et al. Estimating renin participation in hypertension: superiority of converting enzyme inhibitor over saralasin. Am $\mathcal{F}$ Med 1976;61:790-6.

${ }^{16}$ Man in 't Veld AJ, Wenting GJ, Schalekamp MADH. Does captopril lower blood pressure in anephric patients ? Br Med f 1979; ii:1110.

17 Man in 't Veld AJ, Schicht IM, Derkx FHM, De Bruyn JHB, Schalekamp MADH. Effects of an angiotensin-converting enzyme inhibitor (captopril) on blood pressure in anephric subjects. $\mathrm{Br} \mathrm{Med} \mathcal{F}$ $1980 ; 280: 288-90$.

(Accepted 5 February 1980)

\section{Relation between hydrocarbon exposure and the nephrotic syndrome}

Recent reports have emphasised the increased incidence and intensity of exposure to hydrocarbon solvents in patients with chronic glomerulonephritis (in particular Goodpasture's syndrome and proliferative glomerulonephritis) compared with a control population with no renal disease. ${ }^{1-4}$ Rapidly progressive glomerulonephritis in rats exposed to petroleum vapours ${ }^{2}$ or fed $N, N^{\prime}$-diacetylbenzidine ${ }^{5}$ showed that hydrocarbon-induced glomerulopathy does occur. A cause-and-effect relation between hydrocarbon exposure and human glomerulopathies based on statistical data has not been reported, however, except perhaps for the case described by Von Schéele et al.4 All Von Schéele's patients have had chronically deteriorating disease.

\section{Case report}

A man aged 59 years was admitted with all the signs and symptoms of a nephrotic syndrome. At work he had been exposed for prolonged periods to hydrocarbon derivatives. The figure shows the changes in proteinuria, albuminaemia, oedema, and body weight in relation to successive periods of contact with hydrocarbons and rest periods over 27 months of follow-up. The creatinine clearance remained normal, and the patient received no treatment. Clinical and laboratory investigations showed a close correlation between a worsening of the nephropathy and exposure to toxic products at work and the complete reversal of disease activity after leaving that job.

Renal biopsy, carried out with light, immunofluorescence, and electron microscopy, showed the features of a membranous glomerulonephritis. Electron microscopy indicated that adjacent to small, probably recent, deposits on the subepithelial layer of the glomerular basement membrane were many deposits embedded in the membrane, and it also showed electronlucent lacunae.

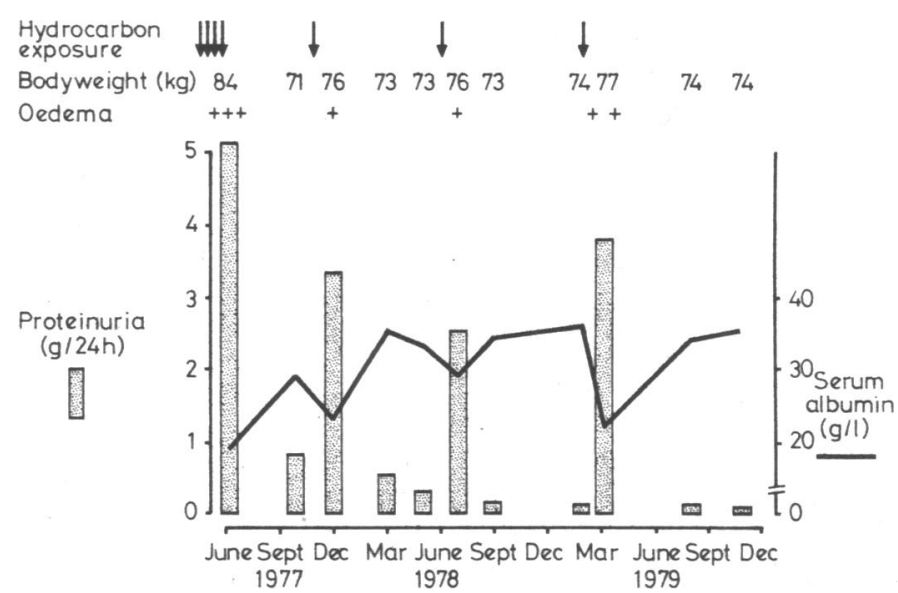

The course of the disease. 